\title{
Major og Schirmers Gaustad
}

Psykiateren Herman Wedel Major planla Gaustad Asyl sammen med sin svoger, arkitekten Heinrich Ernst Schirmer. Planleggingen av Gaustad foregikk parallelt med utarbeidingen av den første norske sinnsykeloven, vedtatt av Stortinget 30. juli 1848. Gaustads arkitektur gir et godt bilde av idealene bak 1800-tallets sinnssykereform. Ikke minst representerer Major og Schirmers Gaustad et brudd med Frederik Holsts ideal om den panoptiske anstalten. Mens Holst og hans arkitekt Christian Heinrich Grosch promoverte en stråleformet anstalt basert på botsfengselstypen, utarbeidet Schirmer og Major et moderne paviljongsykehus med avdelinger som lå fritt i landskapet.

Den banebrytende norske psykiateren Herman Wedel Major (1814-54) (ramme 1) regnes med rette som skaperen av Gaustad Asyl. Han var imidlertid ikke alene. Med seg hadde han svogeren Heinrich Ernst Schirmer (1814-87), en tysk arkitekt som kom til Norge i 1837 og som raskt ble en av det norske 1800-tallets viktigste arkitekter. Schirmer giftet seg i 1843 med Majors søster, Sophia Ottilia Major. Med det begynte et samarbeid som kom til å endre norsk psykiatri så vel som arkitektur.

Denne teksten handler om Gaustad som fysisk omgivelse og forsøker bidra til det som kanskje kan kalles sinnsykereformens arkitekturhistorie. 1800-tallets psykiatriske reformer involverte i aller høyeste grad arkitektur - de fysiske omgivelsene ble sett som viktige faktorer i behandlingen.

\section{RAMME 1}

Herman Wedel Major (1814-54)

Norsk lege og psykiater, regnet som hovedmannen bak den progressive norske sinnssykeloven av 1848. Major var sønn av den irske immigranten Robert Gonsalvo Major og Benedicte Sophie Weidemann. Han studerte medisin i Christiania under professor Frederik Holst og spesialiserte seg senere i psykiatri. Etter omfattende studiereiser $\mathrm{i}$ inn- og utland skrev han Indberetning om Sindssyge-Forholdene i Norge (1846), en radikal kritikk av samtidens sinnssykepleie. Samtidig utarbeidet han Udkast til Lov om Sindssyges Behandling og Forpleining, som lå til grunn for den nye sinnssykeloven av 1848. Major ledet planleggingen av Gaustad Asyl, men valgte av ukjente grunner ikke å søke direktørstillingen der da den ble utlyst vinteren 1854. Major-familien hadde planlagt å emigrere til USA, men omkom ved Cape Race da passasjerskipet Arctis forliste 27. september 1854.

\section{Frederik Holst versus Herman Wedel Major}

Major var ikke den første til å interessere seg for samvirket mellom arkitektur og psykisk helse. Allerede i professor Frederik Holsts Dollhuskommisjon fra 1825 ble omgivelsenes betydning fremhevet. En helbredelsesanstalt måtte ha «passende Beliggenhed, være en sund og sikker Boelig, samt fremme Anledning til Inspektion og Clasification ... At Architekturen heri kunde komme meget til Hjælp, har man først senere erkjendt»,

Arkitekt Christian Heinrich Grosch senere kjent for blant annet universitetsbygningene i Karl Johans gate - tegnet flere urealiserte sykehusprosjekter i samarbeid med Holst, det siste i 1839 (2, s. 89). Det var stjerneformede anlegg organisert omkring en sentralhall etter mønster av samtidens botsfengsler. For Holst var denne typen ideell: «En Bygning, saaledes bygget, at man fra et Punkt af samme kunde oversee den hele, med et Ord, et Panoptikon i den strengeste Betydning, vilde her være at foretrække for alle andre; ... jo mer man kan nærme sig samme, desto bedre er også Architektens Arbeide lykket» (1, s. 13).

Major var Holsts student og var utvilsomt påvirket av professorens mangeårige innsats for en norsk sinnssykereform. Men han delte ikke Holsts arkitektoniske idealer. Den unge legen hadde nye ideer, basert på personlig erfaring, reiser og studier. I 1842 hadde Major - nettopp uteksaminert fra medisinstudiet i Christiania - oppholdt seg en periode ved den progressive psykiateren Peter Willers Jessens asyl i Slesvig, der hans forlovede Fanny Rahbek var innlagt. Opplevelsen gjorde at han senere samme år søkte om et statlig reisestipend for å studere psykiatriske anstalter i Europa $(3,4)$. Han fikk ikke stipendet, men reiste likevel.

I 1843-44 besøkte Major sykehus over hele England og Tyskland og utviklet etter hvert helt nye ideer om hvordan en «hen1844 skrev han begeistret til svogeren om planene: skrev kommisjonen $(1$, s. 11). sigtsmæssig Anstalt» skulle utformes. I april

\section{Mari Hvattum}

mari.hvattum@aho.no

Arkitektur- og designhøgskolen i Oslo

> Se også side 1060

\section{Ordforklaringer}

Panoptikon: Overvåkningsanstalt der flere enkeltceller overvåkes fra et sentralt kontrollpunkt. Betegnelsen stammer fra den britiske filosofien Jeremy Bentham, som beskrev den ideelle overvåkningsanstalt som et sentralt voktertårn omkranset av et sirkulært celleanlegg. På 1800-tallet ble betegnelsen imidlertid også brukt om stråleformede anlegg med kontrollpunktet i midten.

Risalitt: Svakt fremhevet fasadeparti, oftest $i$ hele fasadens høyde. I den klassiske arkitekturen brukes risalitter for å fremheve bygningens midtparti eller - ved symmetriske arrangementer - sidepartier.

Hjørnekvader: Bearbeidet bygningsstein, anvendt til forsterkning og/eller aksentuering av bygningens hjørner. 


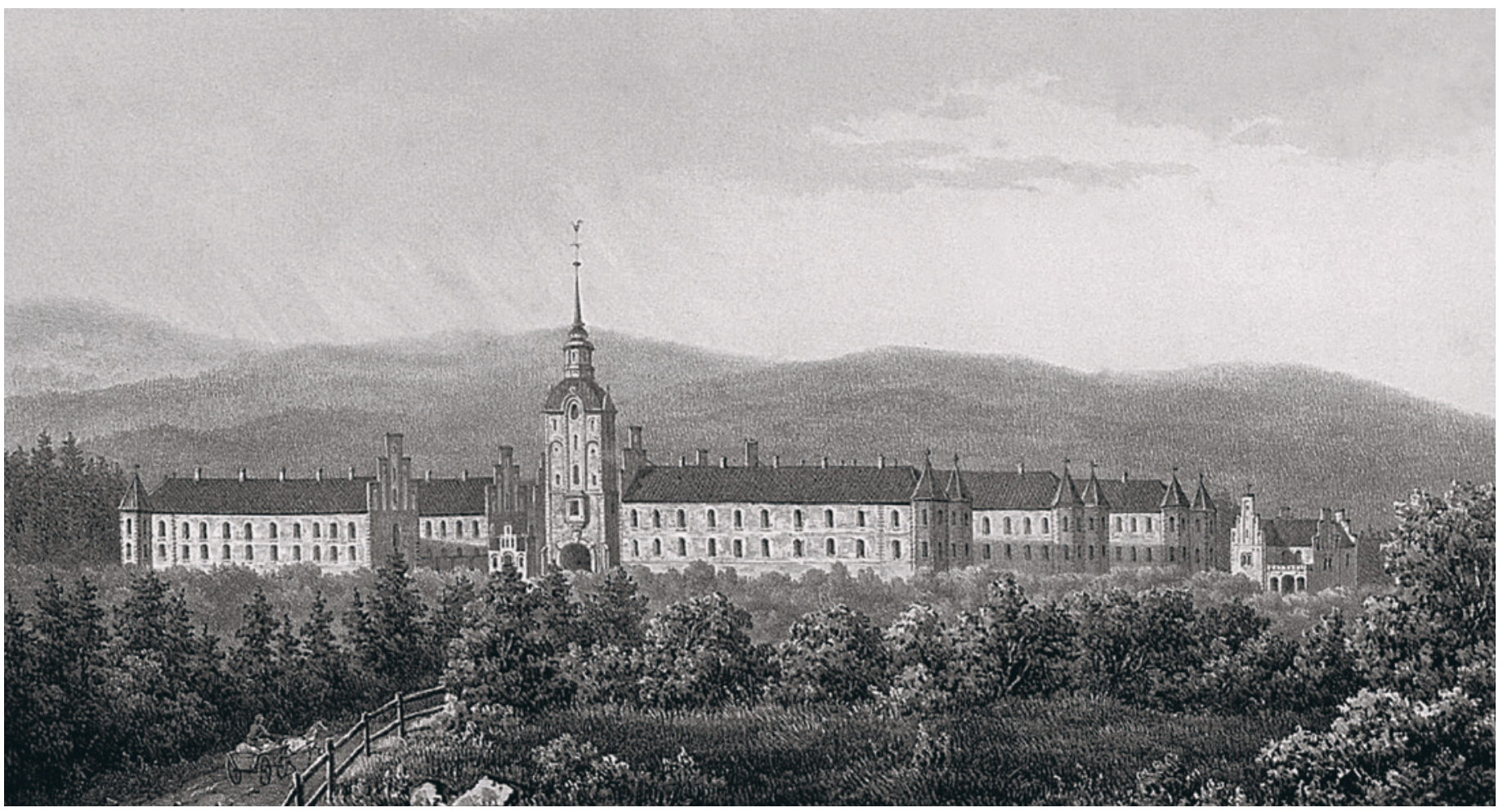

Gaustad Asyl i 1850-årene. Fra C. Tønsberg Christiania med dens nærmeste Omgivelser (13)

[M]in Hovedbestrobelse [maa] vare at komme $i$ Besiddelse af en Plan, der kan raabe af Veien, og som jeg kan putte i Vagtskaalen til min Faveur. For at oppnaae dette forekommer det mig nødvendig at jeg her førend jeg reiser longere udarbeider en saadan med Prf. Jessen, forelagger den for alle Europas store Moend, og endelig gjennom Prf. Damerow i Halle lader den begutachte af den preussiske Bygningscommitée, som den høieste Dommer $i$ denne Anledning. Men hvorledes udarbeide en Plan uden Dig, det er umulig. Baade Jessen og jeg har toenkt derover, og besluttet at skrive til Dig og paa det instcendigste anmode Dig om at ligge her nogle

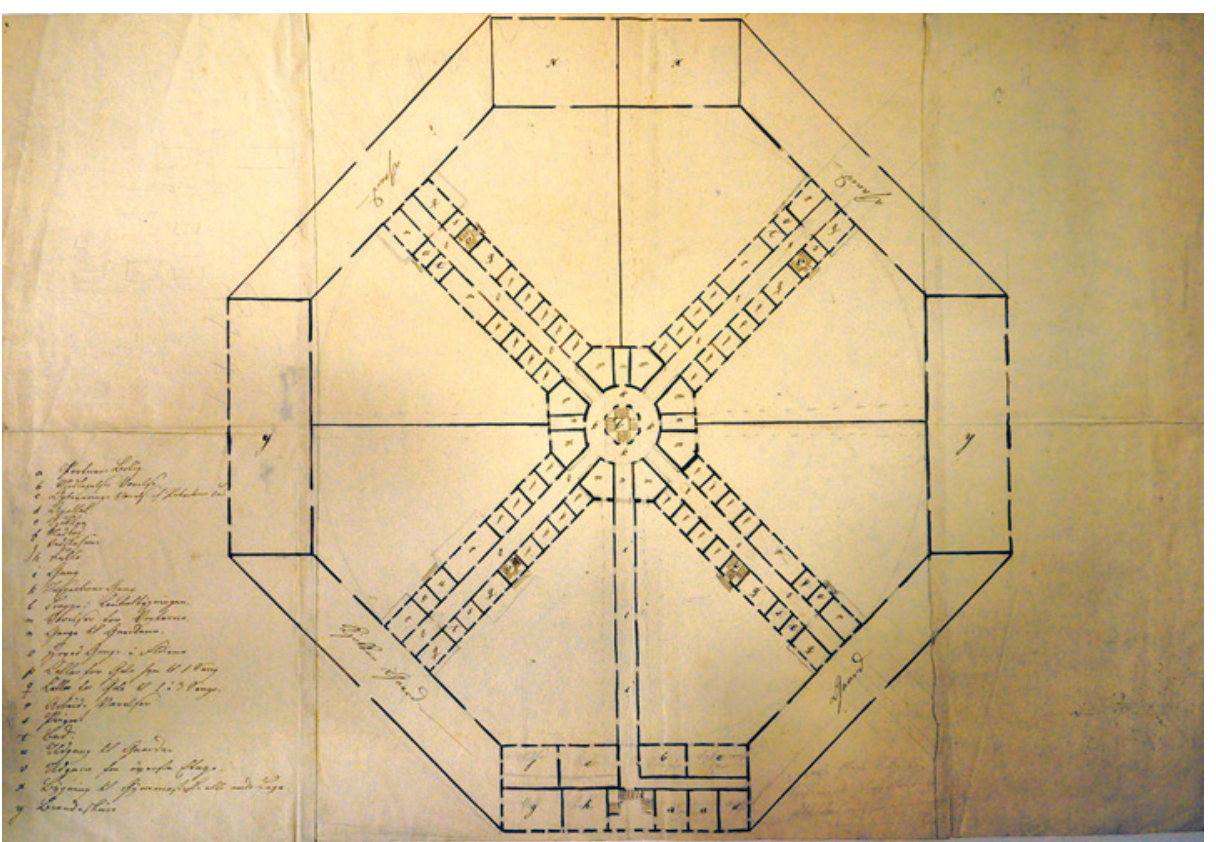

Christian Heinrich Grosch" utkast til sykehus for «Sindssvage». Udatert, trolig 1839, etter oppdrag fra Det Kongelige Frederiks Universitet. Oslo byarkiv
Dage paa din Hjemreise. ... Taenk nu over alt dette, og forsøg om du ikke ligesom mig af din egen og min Fordeel, og Fannys utcemmelige Ønsker kan komponere en Substanz, man kunde kalde Nødvendighed. ... Du vil finde mange foreløbige Arbeider og Beregninger her fcerdige, saaat Arbeidet kunde gaae meget hurtig frem. - Planen maae du og ingen Anden gjøre det er en Scetning hvorifra du maae gaae ud (5).

\section{«Et Sindsyge-Asyl for Norge»}

Schirmer tok oppdraget og arbeidet i rekordfart. Allerede høsten 1844 sendte de to svogrene Forslag til et Sindsyge-Asyl for Norge til Kirke- og undervisningsdepartementet. Forslaget ble publisert i Ugeskrift for Medicin og Pharmacie vinteren 1845 og introduserte ikke bare en ny behandlingsfilosofi, men også en ny type behandlingsinstitusjon (6). Etter en historisk oversikt over sinnssykepleiens utvikling ble det nye mønsteranlegget for 150 pasienter beskrevet. Forslaget kopierte ikke noe eksisterende anlegg, presiserte Major, men samlet og forente løsninger fra ulike institusjoner. Det var ikke drevet av «umoden Theoretiseren eller letsindig Forandrings-Syge», men basert på grundige studier og solid faglig veiledning, ikke minst fra professor Jessen (6, s. 49).

I stedet for Holsts panoptiske anstalt tenkte Major seg et anlegg skapt for behandling, ikke for straff. Med dette avskrev han 
også Holsts foretrukne bygningstype, nemlig stråleformen og overvåkningsprinsippet den innebar. Man trodde lenge, skrev Major, «at kunne opnaae alle Fordele med den panoptiske eller dioptiske Bygnings-Maade, ved hjelp af hvilken Opsynspersonalet med lethed kan oversee det Hele fra et fælles Middelpunkt. Men i deslige panoptiske Bygninger oversaae man ofte kun en grændseløs Forvirring» $(6$, s. 63).

I stedet for en overvåkningsmaskin drømte Major om sykehuset som et kurativt instrument - et instrument de guérison slik de franske psykiaterne Philippe Pinel og Jean-Étienne Esquirol hadde formulert det, der selve behandlingsinstitusjonens utforming var del av behandlingen (7). Dette innebar en rekke fysiske krav. For det første måtte anstalten ligge for seg selv, «uberørt af alle ydre Forholde». Murer og gjerder dugde ikke - behandlingen fordret at pasienten ble tatt ut av sin daglige kontekst, og omgivelsene skulle bidra til denne isolasjonen.

Anlegget var delt inn i fire klasser: første klasse for de rolige og anstendige, annen klasse for de urolige, tredje klasse for de «larmende, voldsomme, trodsige og farlige Syge», fjerde klasse for urenslige og «i Utugt nedsunkne» (6, s. 63). I tillegg ble pasientene skilt i henhold til stand og dannelse, ettersom det ansås uheldig for både rik og fattig om de måtte leve sammen. Sammen med kravet om absolutt adskillelse mellom kvinner og menn utgjorde dette en finmasket og kompleks taksonomi. Schirmer løste oppgaven med en symmetrisk paviljongstruktur, der skillet mellom kvinner og menn gikk langs midtaksen. De frittstående avdelingene ble lagt vinkelrett på midtaksen med hovedbygningen i midten. Her var også hovedinngangen, markert med en midtrisalitt med spir.

Paviljongstrukturen var en progressiv type innen 1800-tallets sykehusarkitektur. Den knyttes ofte til miasmeteorien, altså tanken om at smittsomme sykdommer sprer seg på grunn av «dårlig luft» (8, s. 145-6). At typen også ble foretrukket i psykiatriske anstalter, viser imidlertid at det lå flere idealer bak, ikke minst ønsket om å skape intime og hjemlige omgivelser for de syke.

Forbildene ble hentet fra Europa. Major og Schirmer studerte blant annet Provinzial-Irrenanstalt Halle, ledet av psykiateren Heinrich Damerow, og Illenau Irrenanstalt, som Major anså å være «et av Tydsklands bedste Asyler» (6, s. 57). Begge ble åpnet i 1842 og var varianter av paviljongsykehus. Den viktigste inspirasjonen var allikevel Jessens Hornheim i Kiel, påbegynt i 1843, et lite paviljongasyl tegnet av Alexis de Chateauneuf, med tre frittstående bygninger i en park. Jessen baserte behandlingen på Pinel og Esquirols idealer om frihet
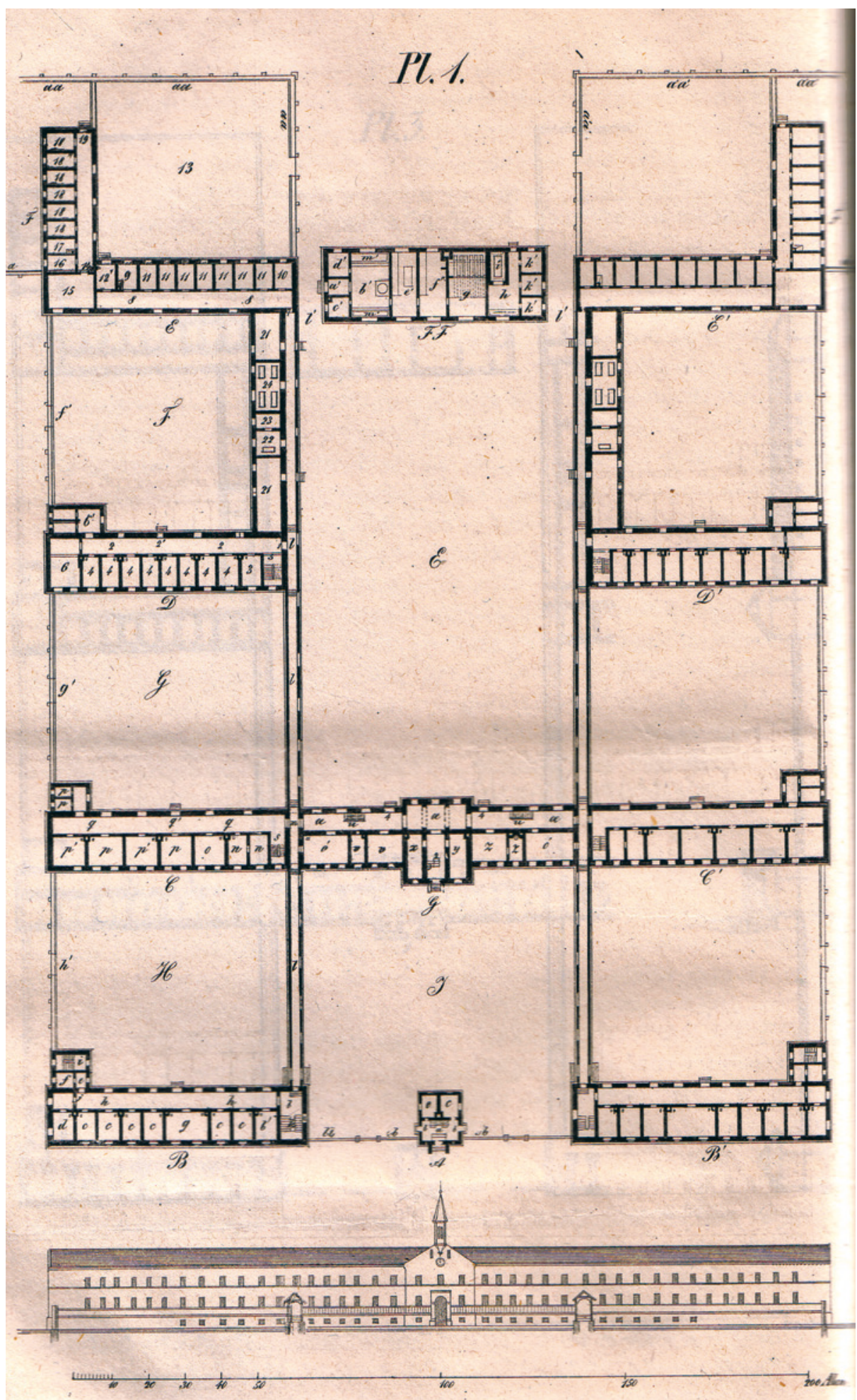

Herman Wedel Major \& Heinrich Ernst Schirmers mønsterplan for et sinnssykehus. Fra Ugeskrift for Medicin og Pharmacie 1845 (6) 


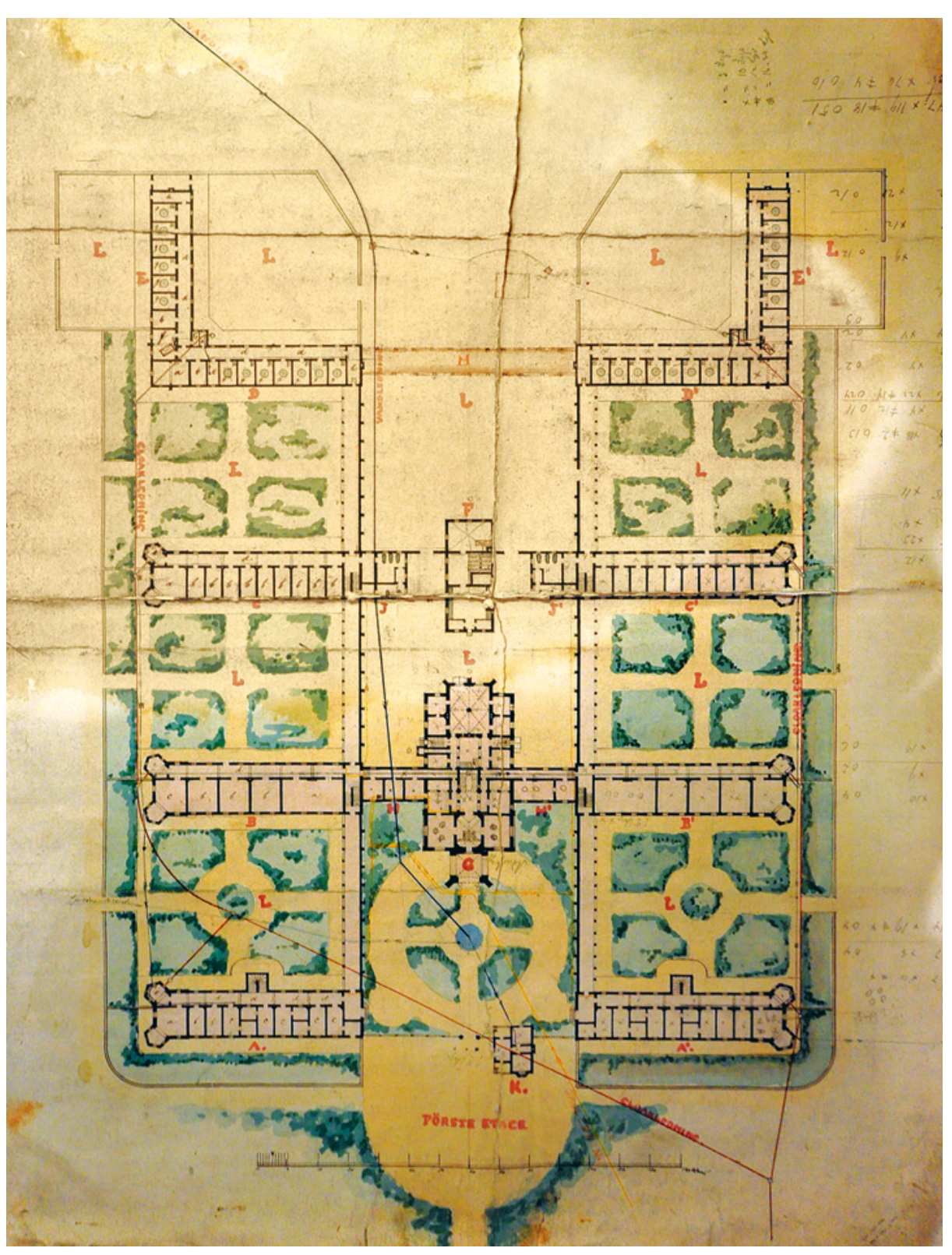

Heinrich Ernst Schirmer og Herman Wedel Majors plan for Gaustad Asyl med hageanlegg. Senere oppmålingstegning, udatert. Gaustad sykehus' arkiv

fra tvang, og hans lille sykehus var følgelig uten gjerder og murer. Major fulgte Jessens eksempel både i det medisinske og det arkitektoniske.

Major og Schirmers 1845-prosjekt demonstrerer til fulle arkitekturens rolle i den nye behandlingsfilosofien. «Bygningenes Ydre maa have et venligt Udseende, og alt Fængselsagtigt - saasom høie Mure, tilgittrede Vinduer - maa undgaaes», formante Major (6, s. 70). I stedet for fengsling og overvåkning skulle pasientene behandles gjennom beskyttende avsondring, riktig kategorisering og meningsfull sysselsetting - alt i tråd med nye europeiske idealer for sinnssykebehandling.

Schirmers paviljongstruktur, med sitt monumentale, men vennlige uttrykk, oversiktlige avdelinger og mange hager og gårdsrom la til rette for dette. En slik avsondret verden ville virke gunstig på pasientenes sjeleliv, mente Major: «Efterhaanden vil det hele indre Liv, som hersker i Asylet, imponere dem ved sin rolige Orden og umærkelig føre dem med sig i Asylets stille, regelmæssige, maskinartede Gang» (6, s. 62).

\section{Planleggingen av Gaustad og sinnssykeloven av 1848}

I 1845 bevilget Stortinget penger til tomtekjøp. Major, som arbeidet som lege ved Christiania Sindsyge-Indrætning (senere Oslo Hospital) fikk ansvar for å lede utbyggingen. Han synes å ha vært selvskreven - verken i stortingsvedtaket eller andre steder diskuteres andre navn. Det var heller ingen diskusjon om arkitekten, trolig hadde Major satt som betingelse at svogeren skulle formgi sykehuset, basert på deres felles plan fra 1845.

Nå begynte planleggingen, ikke bare av én enkelt anstalt, men av en gjennomgripende reform av norsk sinnssykepleie. Major foretok studiereiser i Europa og Norge og utga i 1846 Indberetning om Sindssyge-Forholdene i Norge (9). I tillegg til en kartlegging av de sinnslidendes vilkår inneholdt innberetningen utkast til den sinnssykeloven som ble vedtatt med mindre endringer av Stortinget 30. juli 1848 .

Lovteksten hadde direkte arkitektoniske implikasjoner. Den fordret nye, spesialbygde institusjoner og foreskrev tomtevalg, organisering og utforming. Intet asyl skal autoriseres, fastslår $\S 1$, som ikke oppfyller betingelsene om «Asylets fuldkomne Adskillelse fra alle andre Indretninger; en fri og sund Beliggenhed; Anledning til de Syges Sysselsættelse og Bevægelse i fri Luft; Absolut Afsondring af de forskjælige Kjøn, samt en passende Classification af de Syge» (10, s. 582).

Tomten på Østre Gaustad ble kjøpt i 1847. Beliggenheten var helt i samsvar med Majors idealer. Stedet lå et stykke fra byen, det var frisk luft og sol, skog og jord for brensel og matproduksjon slik at pasientene kunne sysselsettes med hagestell og grønnsaksdyrking. Tomten tilfredsstilte både kravet om isolasjon og intensjonen om meningsfull sysselsetting.

Det var forbausende lite som ble forandret fra Schirmer og Majors 1845-prosjekt til det anlegget som vel ti år senere ble innviet på Gaustad. Selv om antallet pasienter økte fra 150 til 200 (og siden enda mer) og den hellende tomten krevde noen tilpasninger, ble plangrepet fra $1845 \mathrm{i}$ hovedsak beholdt

Planen er basert på et system av frittstående paviljonger, strengt ordnet $i$ henhold til pasientkategoriene. Anlegget er speilet om en symmetrilinje som skiller kvinne- og mannsavdelingene fra hverandre, med driftsog administrasjonsfunksjoner i midten. På hver side av midtaksen ligger fire parallelle fløyer bundet sammen av en åpen kolonnade.

Fra de fremste fløyene var det utsyn over byen og fjorden. Disse var forbeholdt «rolige og anstendige Pasienter fra dannet Klasse». Rolige pasienter fra allmuen ble plassert i andre rad i de såkalte B-fløyene, $i$ henhold til Majors idé om at hver pasient skulle behandles i sitt eget miljø. Bak Bfløyene lå avdeling $\mathrm{C}$, som var for urolige pasienter fra alle samfunnslag. For de sykeste ble altså klassetilhørigheten tillagt mindre rolle. Mens A- og B-avdelingene hadde alminnelige vinduer og oppholdsrom 
med blant annet piano og biljardbord, var avdeling $\mathrm{C}$ enklere utstyrt og hadde lette gitter for vinduene (11, s. 69).

Utvendig var A-, B- og C-avdelingene forholdsvis likt organisert. De toetasjes fløyene var bygd i rød tegl, med bratte, skiferdekkede valmtak. Endeveggene var utstyrt med tårnkarnapp, og de spisse, sekskantede tårnhjelmene ga anlegget et karakteristisk eventyraktig preg. Her lå avdelingenes dagligstuer, med utsikt over skogen og jordbrukslandet omkring. Pasientrommene lå mot sør, og langs nordveggen løp romslige, ensidige korridorer med buehvelv og store vinduer. Selv i dag, etter mange ombygginger, kan man fornemme hvor vakkert lyset og siktlinjene er modulert i de smale fløyene, der pasientene făr stadige utblikk over hagene og gårdsrommene utenfor. Hvert gårdsrom var $30 \times 50$ meter og var planlagt «beplantede og opdyrkede til Lystanlæg» (12). Hageanleggene var vesentlige $\mathrm{i}$ behandlingen, og Major skrev begeistret om «Mark- og Have-Arbeid» som «udføres med Lyst af næsten alle Pasienter» (6, s. 64). Han satte i gang en planteskole for å beskjeftige pasientene og forsyne uterommene på Gaustad med planter.

Helt bakerst lå avdelingene D og E, for henholdsvis urenslige og «larmende, voldsomme, trassige eller farlige» pasienter. Disse avdelingene hadde et separat gårdsrom som vendte vekk fra anlegget for øvrig. De var enkelt utstyrt med gitrede takvinduer, fastskrudde møbler og lett skrånende gulv, slik at søl og avfall skulle kunne spyles vekk. Pleierne kunne observere pasientene i cellene fra et langsgående galleri.

Gaustad var et teknisk avansert anlegg, utstyrt med gasslys, vannbåren gulvvarme og ventilasjonskanaler i alle rom. Det ble installert vannklosetter, men de fungerte ikke tilfredsstillende og ble fjernet i 1865 (11, s. 71-2). Vaskehuset bak sentralbygget tjente som sentralfyr, og flere avdelinger ble varmet opp av varmluft ført i rør fra den store dampkjelen (12).

«En storartet Humanitetsanstalt» Selv om Schirmer stort sett holdt på planløsningen fra 1845 , ble anlegget utviklet betraktelig frem mot byggestart. Det skjematiske eksteriøret fra 1845 ble erstattet av en variert volum- og fasadebehandling. Særlig hovedbygningens inngangsparti ble videreutviklet. Schirmer forkastet risalittmotivet og introduserte i stedet et majestetisk tårn med kobberhette og spir, beliggende for enden av en forplass med springvann og blomster. På siden av plassen ligger portnerboligen i rød tegl, med hjørnekvadre og prydgavler i sandstein. Huset er et av de få elementene som ikke forholder seg til

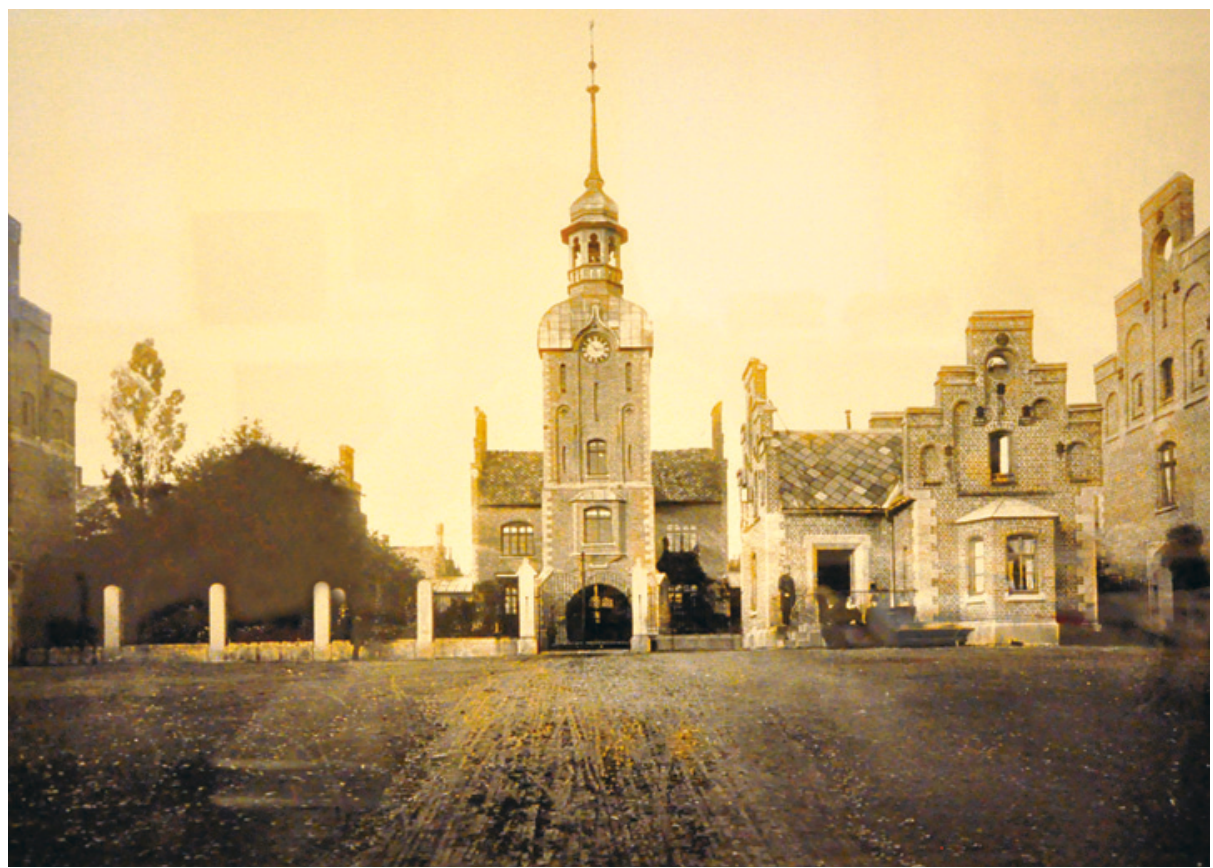

Gaustad Asyl, hovedinngang, udatert. Fotograf ukjent. Gaustad sykehus' arkiv symmetriaksen, og det utgjør et pittoresk lite unntak i komposisjonen. I pakt med Majors (og Jessens) visjon var Gaustad for øvrig et asyl uten murer - det opprinnelige anlegget var bare omkranset av et stakittgjerde.

Allerede i forslaget fra 1845 hadde Major vært opptatt av asylets visuelle effekt. Han skrev levende om «Vigtigheden af det Indtryk, som frembringes hos den Syge ved den første Indtrædelse i Asylet (...) Disse ville paa eengang imponere dem, og, lige fra det Øyeblik, de træde indenfor Sphæren af Asylets Virksomhed, ustanselig føre dem med i den regelmæssige Gang» (6, s. 66).

Schirmer tok Majors visjon på alvor. I motsetning til det stramme 1845-prosjektet er det endelige anlegget storslått og variert, selv innenfor klassifikasjonssystemets strenge orden. Selv om ingen av enkeltbygningene er særlig store, får de lange fløyene med hovedbygnigen i midten

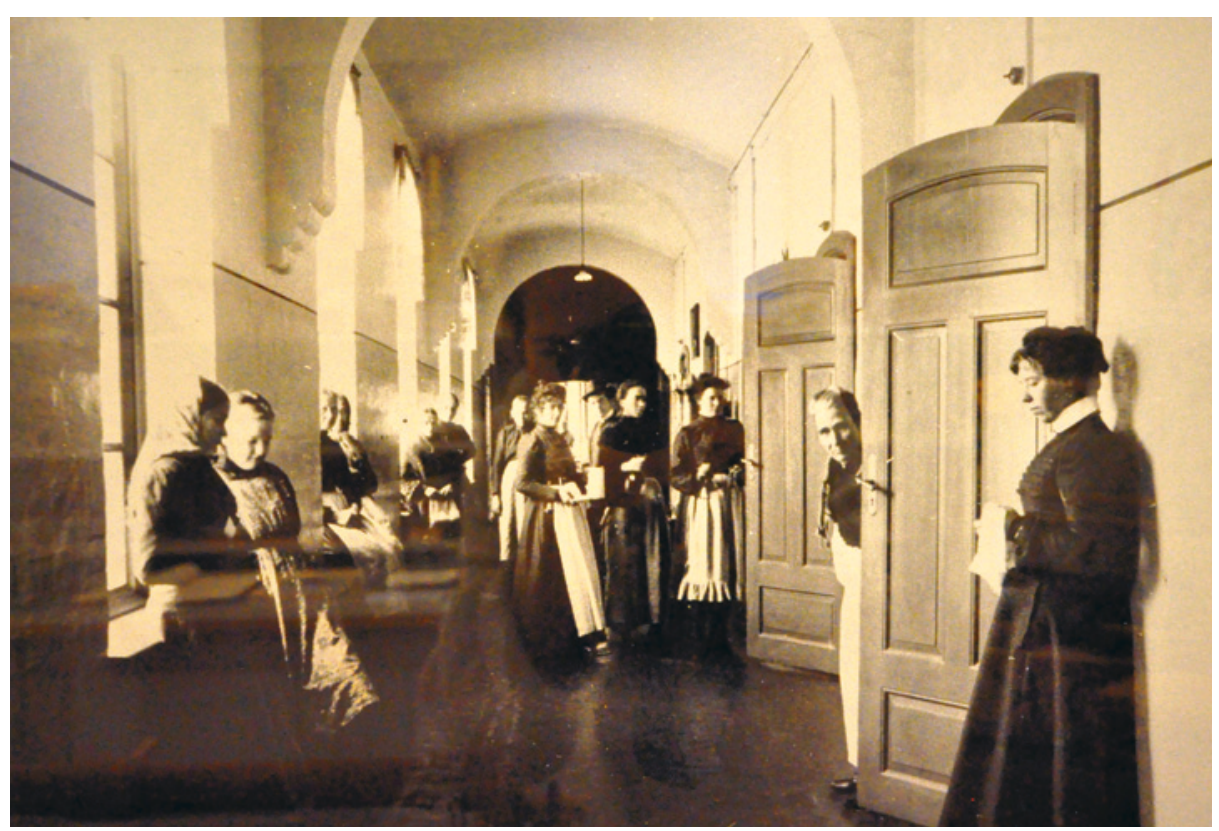

Gaustad Asyl, korridor i kvinnefløyen, avdeling B. Udatert, trolig omkring 1870. Fotograf ukjent. Gaustad sykehus' arkiv 
det til å se ut som et Soria Moria slott med tårn og gavler. I den påkostede guideboken Christiania med dens noermeste Omgivelser fra 1854 beskrev Christian Tønsberg Gaustads «ædle og dristige Stiil, og maleriske Beliggenhed» og mente sykehuset bidro til «at forskjönne den allerede i sig selv, baade af Natur og Kunst saa rigt smykkede Egn» (13). Rosen rimer med mottagelsen for ørig. Gaustad ble ansett for å være usedvanlig vellykket og beskrives som «en af de mest storartede og vellykkede blant de mange Humanitetsanstalter, Fædrelandet i det sidste halve Aarhundrede har kunnet glæde sig ved» $(14$, s. 18$)$.

I 1871 sendte Gaustads daværende direktør Ole Sandberg en kopi av 15-årsberetningen for Gaustad Asyl til Schirmer. Sammen med beretningen lå en udatert note som fortsatt finnes på Nasjonalbiblioteket: «Et ringe Tegn på den Taknæmlighet, hvormed jeg daglig under min Embedsgjærning ihukommer den Mand, hvem Asylet skylder sin hensigtsmæssige og solide Indretning» (15).

\section{Mari Hvattum (f. 1966)}

er arkitekturhistoriker og professor ved Arkitektur-og designhøgskolen i Oslo. Hun forsker på 1800-tallshistorisme og er forfatter av monografien Heinrich Ernst Schirmer. Kosmopolittenes arkitekt (Pax, 2014).

Forfatter har fylt ut ICMJE-skjemaet og oppgir ingen interessekonflikter.

\section{Litteratur}

1. Holst F. Beretning, Betænkning og Indstilling fra en til at undersøge de Sindsvages Kaar i Norge og gjøre Forslag til deres Forbedring i Aaret 1825 naadigst nedsat Kongelig Commission. Christiania: Lehmanns Enke, 1828: 11.

2. Hvattum M. Heinrich Ernst Schirmer. Kosmopolittenes arkitekt. Oslo: Pax, 2014

3. Major HW. Stipendieansøgning af 22.12.1842, Nasjonalbibliotekets håndskriftsamling Ms. $4^{\circ}$ 2408.

4. Søbye E. En mann fra forgangne århundrer. Overlege Johan Scharffenbergs liv og virke 1869-1965. En arkivstudie. Oslo: Oktober, 2010

5. Major HW. Brev til Heinrich Ernst Schirmer, 22.4.1844, Nasjonalbibliotekets håndskriftsamling Ms. $4^{\circ} 2408$.
6. Major HW, Schirmer HE. Forslag til et SindsygeAsyl for Norge. Ugeskrift for Medicin og Pharmacie 1845, nr. 7-10: 49-74.

7. Skålevåg SA. Constructing curative instruments: psychiatric architecture in Norway, 1820-1920. Hist Psychiatry 2002; 13: $51-68$

8. Bjerkek OP. Retterstøl N. «En reforms idealanlegg». Fortidsminneforeningens årbok 2000. Oslo: Fortidsminneforeningen, 2000: 137-55.

9. Major HW. Indberetning om Sindssyge-Forholdene i Norge i 1846. Christiania: Schibsted, 1846.

10. Lov om Sindsyges Behandling og Forplejning. Stortingsforhandlinger 1848, 6. del: 582-584.

11. Austad AK, Ødegård $\emptyset$. Gaustad sykehus gjennom hundre år. Oslo: Gundersen, 1956

12. Sandberg O. Generalberetning fra Gaustad Sindssygehus, Aaret 1856. Christiania: Gaustad, 1857.

13. Tønsberg C. Christiania med dens nærmeste omgivelser. Christiania: Tønsberg, 1854.

14. Sandberg O. Gaustad 1855-1870. Christiania: Steenske Bogtrykkeri, 1871.

15. Sandberg O. Brev til Heinrich Ernst Schirmer udatert. Nasjonalbibliotekets håndskriftsamling Brevs. 266 